\title{
Seed dispersal by Ceratogymna hornbills in the Dja Reserve, Cameroon
}

\author{
KENNETH D. WHITNEY* ${ }^{+}$, MARK K. FOGIEL*, AARON M. \\ LAMPERTI*, KIMBERLY M. HOLBROOK*, DONALD J. STAUFFER*, \\ BRITTA DENISE HARDESTY*, V. THOMAS PARKER* and THOMAS B. \\ $\mathrm{SMITH}^{* \dagger}$
}

*Department of Biology, San Francisco State University, 1600 Holloway Avenue, San Francisco, California 94132 U.S.A.

$\dagger$ Center for Population Biology, University of California, Davis, California 95616-8755 U.S.A.

(Accepted 13 January 1998)

\begin{abstract}
Seed dispersal is a process critical to the maintenance of tropical forests, yet little is known about the interactions of most dispersers with their communities. In the Dja Reserve, Cameroon, seed dispersal by the hornbills Ceratogymna atrata, C. cylindricus and C. fistulator (Aves: Bucerotidae) was evaluated with respect to the taxonomic breadth of plants dispersed, location of seed deposition and effects on seed germination. Collectively, the three hornbill species consumed fruits from 59 tree and liana species, and likely provided dispersal for 56 of them. Hornbill-dispersed tree species composed 22\% of the known tree flora of the site. Hornbill visit lengths, visit frequencies, and seed passage times indicated that few seeds were deposited beneath parent trees; in five hornbill/tree species pairings studied, $69-100 \%$ of the seeds ingested were deposited away from the parent trees. Germination trials showed that hornbill gut passage is gentle on seeds. Of 24 tree species tested, 23 germinated after passage by hornbills; of 17 planted with controls taken directly from trees, only four species showed evidence of inhibition of germination rate, while seven experienced unchanged germination rates and six experienced enhanced germination rates. Results suggested that Ceratogymna hornbills rank among the most important seed dispersers found in Afrotropical forests, and they deserve increased conservation attention. Ceratogymna hornbills are likely to become increasingly important in forest regeneration as populations of larger mammalian seed dispersers (such as forest elephants and primates) diminish.
\end{abstract}

KEY WORDS: birds, Ceratogymna, diet, frugivory, rain forest, seed deposition, seed dispersal, seed germination, seed passage

\footnotetext{
${ }^{1}$ To whom correspondence should be addressed, at the Center for Population Biology, UC Davis, Davis CA 95616-8755, USA.
} 


\section{INTRODUGTION}

Seed dispersal by frugivorous animals is widely recognized as a crucial process in tropical forests (Herrera 1995; Howe 1984, 1990; Stiles 1985, Stiles 1992, Willson 1992). The disruption of tropical forest ecosystems worldwide makes an understanding of this process important. Unfortunately, we still lack basic natural history information for many systems. While certain seed dispersal relationships have been well studied in the tropics, for example Virola nobilis and toucans in the Neotropics (Howe 1983, 1986; Howe \& Vande Kerckhove 1981, Howe et al. 1985) and Cola lizae and gorillas in the Afrotropics (Tutin et al. 1991), the assessment of the community-wide importance of particular dispersers is rarely carried out. Surveys of frugivore assemblages and frugivore diets, while extremely valuable, can only outline the potential interactions. Further work is needed to substantiate the relative importance of different dispersers within tropical forest communities.

Depending on the scale of interest, the approaches to evaluating disperser importance vary. From the standpoint of an individual plant, the relative importance of a seed-dispersing species is determined by its 'effectiveness', defined as its contribution to plant fitness (Bustamante \& Canals 1995, Schupp 1993). In the system of Schupp (1993),

$$
\text { effectiveness }=\text { quantity } \times \text { quality }
$$

where quantity is the number of seeds dispersed, and quality is the probability that a dispersed seed will produce a new reproductive adult. Quantity is a function of (1) the number of visits to the plant and (2) the number of seeds dispersed per visit, while quality is determined by (3) the quality of seed treatment in the mouth and gut and (4) the probability that a deposited seed will survive and become an adult (Schupp 1993). Components 1-3 are comparatively easy to assess through watches at fruiting plants and germination testing of seeds handled by frugivores. In contrast, component 4 is very difficult to assess because of the large spatial and temporal scales involved in determining the actual fates of dispersed seeds.

From the standpoint of a plant community, determination of the relative importance of a seed-dispersing species is not as evident as it is in the case of an individual plant. Two approaches seem promising in theory. A reductionist approach, based on examination of all individual disperser-plant relationships, would allow disperser species to be ranked based on their effectiveness summed across all fruiting plant species. In this vein, Herrera (1984) constructed pairwise estimates of the dispersal importance of each member of an avian disperser assemblage (14 species) to each member of a fruiting plant assemblage (17-19 species) in Spanish scrublands. Clearly, this approach is impractical in tropical forests, where numbers of both fruiting plant species and frugivore species routinely number in the hundreds. An experimental approach, involving perturbation of the system (see Bender et al. 1984) via the removal of 
disperser species and subsequent monitoring of plant reproduction and forest structure, would sidestep the problems of a reductionist study. However, obvious constraints in tropical forests - including the fact that many forest organisms operate at vastly larger temporal scales than their observers, the high mobility of most frugivores and seeds, and the ethical and logistical problems of performing large-scale manipulations - render an experimental approach impractical as well.

Given the constraints on the approaches outlined above, we introduce here three criteria for evaluating the community importance of seed dispersers in tropical forests. These criteria should facilitate the identification of key seed dispersers, and thus provide immediate conservation benefits. These criteria are not exhaustive, and furthermore some frugivorous species may violate one or more of them while still remaining important agents of dispersal. However, we hypothesize that the more a particular species conforms to these criteria, the more important it is likely to be in dispersal.

A disperser important to the community will be likely to:

\section{Consume the fruits and disperse the seeds of a large proportion of the flora.}

Dispersers that interact with only a few plant species can have important effects, if one or more of those species are 'keystone' plant species (e.g. Howe 1986). However, the lack of an operational definition for keystone species (Mills et al. 1993), and the large number of species in tropical forests, suggests that a search for keystone plant species and their dispersers is not likely to be a productive exercise. We hypothesize that highly frugivorous species that disperse a large number of different plant taxa will have consistently greater impacts on regeneration in tropical forest communities than species that disperse fewer plant taxa.

2. Move most seeds it handles away from the parent plant.

Frugivores that drop or pass large numbers of seeds while still in or under the parent plant are not likely to be effective dispersers. Although survival underneath parents is possible for some seeds and seedlings, many species experience high rates of mortality beneath parents (Chapman \& Chapman 1995, 1996; Howe 1990). Historically, lengths of visits to fruiting plants that are shorter than seed passage times are taken as evidence for effective dispersal (e.g., Pratt \& Stiles 1983). However, short visit lengths relative to seed passage times do not guarantee that seeds will be dispersed away from the parent. Frugivores may revisit a fruiting plant and deposit seeds ingested during earlier visits. To predict the percentage of seeds dispersed away from a parent plant, it is necessary to compare the temporal pattern of frugivore visitation (including repeat visits) with the timing of seed passage.

3. Process most fruits in a manner that has neutral or beneficial effects on seed germination.

Fruit processing (which includes, in the case of endozoochory, handling prior to ingestion, ingestion, and gut passage ending with either defaecation or 
regurgitation) can result in damage to seeds. Frugivores that damage a large proportion of the seeds they process are not likely to be effective dispersers. Testing of seeds passed by effective dispersers should show that germination rates are unaffected or enhanced relative to controls.

In this study, we use the above criteria to examine whether three species of hornbills in the genus Ceratogymna are important seed dispersers in the forest community of the Dja Reserve, Cameroon. The seven species in this genus are large, $0.5-2.1-\mathrm{kg}$ canopy birds and are common members of frugivore assemblages throughout tropical rainforest in Africa (Kemp 1995). Previous work has shown that diets of Ceratogymna hornbills contain a wide variety of fruits (Brosset \& Erard 1986, Dowsett-Lemaire 1988, Gautier-Hion et al. 1985, Kalina 1988). Based on inspection of seeds for physical damage, Kalina (1988) and Gautier-Hion et al. (1985) reported few instances of damage in seeds passed by Ceratogymna hornbills. However, neither effects on germination nor seed deposition patterns have yet been examined for these species. This study is an attempt to collect and interpret diet, seed deposition, and seed germination information in a unified manner to better understand the role of hornbills in tropical forest dynamics.

\section{STUDY SITE AND SPECIES}

Data were gathered between January 1994 and December 1996 in the Dja Reserve, southern Cameroon. At 526,000 ha, the Dja Reserve is the largest protected area in Cameroon and is an IUCN Biosphere Reserve (IUCN 1987). The vegetation is semi-deciduous tropical rain forest (Letouzey 1968), and has strong affiliations with other regions of the Congo Basin forest to the south and weaker affiliations with the evergreen Atlantic coastal forest to the west. Elevations in the Reserve range from 400-800 m. The climate is characterized by two wet and two dry seasons, with the major and minor rainfall peaks in September and May, respectively. Annual rainfall in the region is $c .1600 \mathrm{~mm}$ (Laclavère 1980); annual rainfall at the study site was 1669, 1556 and $1522 \mathrm{~mm}$ during the course of the study.

Work was carried out within a $25-\mathrm{km}^{2}$ square centred on the Bouamir Research Station (BRS) $\left(3^{\circ} 11^{\prime} 27^{\prime \prime} \mathrm{N}, 12^{\circ} 48^{\prime} 41^{\prime \prime} \mathrm{E}\right)$. This area has never been commercially logged or farmed, has not been exploited for village agriculture in at least the past $90 \mathrm{y}$ (J.-M. Froment, pers. comm.), and is $22 \mathrm{~km}$ from the nearest village or road. Four main habitat types occur at the BRS: upland forest, Raphia swamp, Uapaca swamp, and inselberg-associated forest (for further information, see Whitney \& Smith, 1998). Currently, 230 species of trees are known from the site (M. Fogiel, unpubl. data), while the diversity of lianas is unknown.

Four species of hornbills in the genus Ceratogymna occur in the Dja Reserve (Christy 1994). Three species were the focus of this study: the black-casqued 
hornbill C. atrata, the white-thighed hornbill C. cylindricus albotibialis, and the piping hornbill C. fistulator sharpii. Adult male body masses are $c .1 .3,1.3$ and $0.5 \mathrm{~kg}$, respectively, for the three species (Kemp 1995). C. subcylindricus is rare in most parts of the Dja Reserve (R. Fotso, pers. comm.) and has not been observed at the BRS study site.

\section{METHODS}

\section{Hornbill diets}

Diet lists for each hornbill species were compiled using two methods: direct observations of birds and seed trapping at nest cavities. Direct observations were made on a weekly basis between January 1994 and December 1996. Groups of birds were located during morning and afternoon walks of the 34.5-km trail system, which traverses all of the major habitat types of the BRS. Observers frequently left the trail system to follow foraging birds. A fruit species was designated as a diet item if either, (a) a hornbill species was observed ingesting it, or (b) a hornbill species was observed to pass (defaecate or regurgitate) its seed. Identifications of insects in hornbill diets were limited to the family or order level. In total, over 1400 direct observations were made (Table 1).

In addition to direct diet observations, hornbill diet was sampled during the nesting season via seed trapping at nest cavities. Trapping was carried out in 1995 and 1996 but not in 1994, a year in which no active Ceratogymna hornbill nests were found despite intensive searches of the study area. A high volume of seed and fruit fall is characteristic beneath active hornbill nests. During the 4-6 mo nesting period, the male hornbill delivers food items to the female and chicks sealed within the nest. Fruit dropping during delivery, seed passage by the male, and seed passage by the nest occupants all contribute to the fruit and seed rain beneath hornbill nest cavities (Kalina 1988, Kinnaird in press). Traps consisted of $1.0-\mathrm{m}^{2}$ polyethylene sheets with small holes for drainage, attached to a square wooden frame and suspended $c .1 .5 \mathrm{~m}$ above the ground.

Table 1. Numbers of diet observations, seed trapping effort, and diet composition (fruits vs. insects) of Ceratogymna hornbills, Dja Reserve, 1994-1996.

\begin{tabular}{lccc}
\hline & C. atrata & C. cylindricus & C. fistulator \\
\hline Direct Observations & a & & \\
$\quad$ No. & 729 & 646 & 74 \\
$\quad$ Percentage & & & 90.5 \\
$\quad$ on fruit & 93.7 & 92.4 & 9.5 \\
$\quad$ on insects & 6.3 & \multicolumn{2}{c}{1} \\
Seed Traps & 22 & 17 & 522 \\
$\quad$ No. Nests Trapped & 4088 & 4710 & \\
$\quad$ No. Seeds Collected & & & \\
\hline
\end{tabular}

${ }^{a}$ The majority $(1,404)$ of the observations were made in mature forest at the BRS. The remaining 45 (8 for C. atrata, 26 for C. cylindricus, and 11 for C. fistulator) were made opportunistically in secondary forest $22 \mathrm{~km}$ from the BRS. 
Each nest received a single trap, placed to capture the highest volume of falling seeds and other nest debris. Traps were erected 4-6 wk after the nests were sealed (1995 sampling) or prior to the nesting season (1996 sampling) to minimize disturbance to the breeding birds. Collections were made approximately three times per month while nests were active, and trapped seeds and fruits were identified to species. Nest-trapping effort is given in Table 1.

\section{Temporal patterns of hornbill visits and seed passage}

Feeding visit lengths of hornbills and other frugivores were recorded during watches of fruiting trees ('focal trees'). Ten species of focal trees were watched for a total of $894 \mathrm{~h}$ during 1994. Observers were concealed on the ground in a position to view as much of the focal tree canopy as possible through binoculars. Watches took place from $0630-1030 \mathrm{~h}$ and from 1400-1800 h, in all weather conditions but rain. Observers recorded the number and identity of visitors, their arrival and departure times, and general behaviour (feeding or resting). Only visits in which the animal exhibited feeding behaviour were included in the feeding visit length calculations. Partial visits (those beginning or ending outside of the observation period) were excluded. Both median and mean visit lengths are reported; the former are not sensitive to extreme values, and thus are most useful in interpreting frugivore behaviour in relation to seed passage times (Wheelwright 1991), while the latter are useful for making comparisons with published data.

The temporal pattern of hornbill presence in fruiting trees was assessed from the focal tree watch data as follows: for each hornbill visit, starting with the time of arrival, the remaining time in the watch period was divided into 1 -h intervals. For each interval, the number of minutes spent in the tree by the hornbill (or returning conspecifics, since individual birds could not be identified with high accuracy once they left) was calculated, as well as the number of minutes the tree was observed. Hornbill presence was then calculated as the ratio of hornbill minutes to observation minutes, and average presence values were calculated from all hornbill visits to a particular tree species. Because of the necessity of recording conspecifics, average presence values overestimate the actual presence of hornbills, probably by a large margin.

Seed passage times were established experimentally via trials with captive hornbills. One individual of each of the three Ceratogymna species was captured with aerial mist-nets and confined in a 1-m $\times 1-\mathrm{m} \times 2-\mathrm{m}$ aviary for 26-48 $\mathrm{h}$. Ripe fruits, known to be part of the hornbill diet, were collected from the forest and were fed at 30-45 min intervals from 0600 to $1400 \mathrm{~h}$. Fruits were placed into the throat, the bill was carefully closed, and the bird was observed to ensure that swallowing occurred. Seeds that were easily pierced with a needle were marked with a short strand of coloured cotton thread to aid in identification after passage. Fruits of species not easily marked in such a manner were fed only once within a 24-h period. Supplemental foods (papaya, raisins) were fed with most trials. During the day (0600-1900 h), each bird was observed 
continuously from a blind near the aviary, seeds were removed from the aviary immediately upon passage, and exact passage times were recorded. During the night, each bird was checked at 1-3-h intervals, and seeds were assigned minimum passage times corresponding to the beginning of the interval in which they were passed.

The distributions of seed passage time and timing of hornbill presence were then compared graphically in order to estimate patterns of seed deposition for five hornbill/tree species pairings. The proportion of seeds each hornbill species was likely to pass beneath parent plants, versus the proportion carried away, was estimated.

\section{Hornbill effects on seeds}

The effects of hornbills on seeds were assessed in two ways. For 34 plant species, seeds passed by hornbills were inspected for obvious physical damage; these seeds were collected from nest traps, seed passage trials, and opportunistically during feeding observations. For a subset of 24 of these species, germination was assessed using outdoor plantings at the BRS; seven of these species were planted without, and 17 with, controls. Because the route of seed passage (defaecation or regurgitation) was unknown for most seeds, all seeds collected from hornbills were grouped for analysis.

Plantings took place from August-November 1994 and from July-October 1995. Seeds passed by hornbills were collected opportunistically during feeding observations (1994 plantings) or from nest traps (1995 plantings). Control seeds were obtained by manually removing fruit pulp from fruits gathered directly from plants. Seeds were stored on thoroughly dried soil in a heavily shaded environment, and storage times did not exceed one week before planting. Seeds were planted in 1-litre nursery bags in a small, $100-\mathrm{m}^{2}$ forest gap. In both years, five to six seeds were planted per bag, at a depth of $1.0 \mathrm{~cm}$. In 1994, bags were placed on a low platform and were exposed to normal daylight, but covered with a clear plastic tent during nights and periods of rain. Bags were watered (c. $75 \mathrm{ml}$ per bag) every other day. In 1995, bags were placed in shallow trenches in the ground to simulate soil temperature and moisture conditions, and were subject to normal rainfall supplemented with $c .100 \mathrm{ml}$ per bag once a week when rainfall was low. In both years germination was monitored weekly for at least 9 mo following planting. After germination, seedlings were removed or marked with a small stick to avoid double-counting. Comparisons of germination rate between controls and treatments were made with a $2 \times 2$ contingency table and Fisher's exact test using the Bio $\Sigma$ tat package (Pimentel \& Smith 1990).

\section{RESULTS}

\section{Hornbill diets}

Each of the three hornbill species was found to be highly frugivorous. Based on frequency of consumption, fruit comprised over $90 \%$ and insects comprised 
less than $10 \%$ of the diet of each species (Table 1). The majority of the insects in hornbill diets were either termites (Isoptera) or winged ants (Formicidae). There appears to be a slight trend towards increased frugivory with increasing body mass; $C$. atrata, the largest of the three species, had the most frugivorous diet, whereas $C$. fistulator ranked lowest in both body mass and percentage of fruits in the diet.

Each of the three hornbill species consumed fruits from 25 to 49 species of trees and lianas (Table 2). Species accumulation curves (Figure 1) indicate that further sampling is unlikely to substantially increase the recorded diet diversity of $C$. atrata and $C$. cylindricus. However, further sampling is likely to lengthen the diet list for $C$. fistulator, for which fewer feeding observations were made; thus the diet of $C$. fistulator may well be as diverse as that of $C$. atrata and $C$. cylindricus. Together, the three species consumed fruits from 59 species in at least 20 plant families, and likely dispersed 56 of these species without damage (see below). Favoured plant families, measured in terms of the number of fruit species consumed, included the Annonaceae (9 spp), Moraceae (7+), Euphorbiaceae (6+), Meliaceae (4), Olacaceae (4), and Myristicaceae (3).

Currently, 230 tree species are known from the BRS study area (M. Fogiel, unpubl. data). C. atrata disperses seeds of at least 42 tree species (Table 2), suggesting that this hornbill species is dispersing $c .18 \%$ of the tree flora. $C$. cylindricus and C. fistulator disperse seeds of $c .20$ and $10 \%$ of the tree flora, respectively. Together, the three Ceratogymna species provide seed dispersal for at least 50 tree species, equivalent to $22 \%$ of the tree flora of the study area. The three Ceratogymna species disperse seeds of at least five species of lianas as well (Table 2).

\section{Temporal patterns of hornbill visits and seed passage}

Visit lengths to fruiting trees were short for all three Ceratogymna species (Table 3). While visits ranged from $<1$ to $76 \mathrm{~min}$, median visit lengths to all tree species were $<18 \mathrm{~min}$, and the majority of visits were $<10 \mathrm{~min}$. Hornbills did return to fruiting trees within $4 \mathrm{~h}$ of a feeding bout, but generally spent little time on these repeat visits (Figure 2). The maximum revisitation observed was for C. cylindricus and the nutmeg Staudtia stipitata; individuals of this hornbill species were present for an average of $31 \%$ of the third hour following a feeding bout.

Of 102 fruits fed to the captive hornbills, exact seed passage times were recorded for 92 (90\%). Of the remainder, eight were passed outside the continuous observation period but before the bird was released; these seeds were assigned a minimum passage time as described in the methods. A final two seeds were not recovered, and were either lost from the cage or were not passed by the time the bird was released. These seeds were excluded from the analysis. With the exception of four Staudtia stipitata seeds regurgitated by C. fistulator, all seeds were defaecated. None of the passed seeds showed signs of damage, 
Table 2. Fruits in the diets of Ceratogymna hornbills in Dja Reserve, Cameroon, 1994-1996.

\begin{tabular}{|c|c|c|c|c|c|}
\hline \multirow[b]{2}{*}{ Fruit species } & \multirow{2}{*}{$\begin{array}{c}\text { Plant } \\
\text { stature }^{\mathrm{a}}\end{array}$} & \multirow{2}{*}{$\begin{array}{l}\text { Seed } \\
\text { fate }^{b}\end{array}$} & \multicolumn{3}{|c|}{ Observations $^{c}$} \\
\hline & & & C. atrata & C. cylindricus & C. fistulator \\
\hline \multicolumn{6}{|l|}{ Anacardiaceae } \\
\hline Lannea welwitschii & $\mathrm{T}$ & $1 \dagger$ & $\mathrm{F}, \mathrm{N}$ & $\mathrm{F}, \mathrm{E}, \mathrm{N}$ & $\mathrm{F}, \mathrm{N}$ \\
\hline \multicolumn{6}{|l|}{ Annonaceae } \\
\hline Cleistopholis glauca & $\mathrm{T}$ & $1 \dagger$ & $\mathrm{F}, \mathrm{E}, \mathrm{N}$ & $\mathrm{F}, \mathrm{E}, \mathrm{N}$ & $\mathrm{F}, \mathrm{N}$ \\
\hline Cleistopholis patens & $\mathrm{T}$ & $1 \dagger$ & $\mathrm{FS}, \mathrm{N}$ & $\mathrm{F}, \mathrm{N}$ & $\mathrm{N}$ \\
\hline Cleistopholis sp. 3 & $\mathrm{~T}$ & $1 \dagger$ & $\mathrm{N}$ & $\mathrm{N}$ & - \\
\hline Enantia chlorantha & $\mathrm{T}$ & $3 \dagger$ & $\mathrm{F}, \mathrm{E}, \mathrm{N}$ & $\mathrm{F}, \mathrm{E}, \mathrm{N}$ & $\mathrm{F}, \mathrm{N}$ \\
\hline Pachypodanthium staudtii & $\mathrm{T}$ & 1 & $\mathrm{~F},, \mathrm{~N}$ & - & - \\
\hline Polyalthia suaveolens & $\mathrm{T}$ & $1 \dagger$ & $\mathrm{F}, \mathrm{N}$ & $\mathrm{F}, \mathrm{E}, \mathrm{N}$ & $\mathrm{N}$ \\
\hline Xylopia hypolampra & $\mathrm{T}$ & $1 \dagger$ & $\mathrm{F}, \mathrm{E}, \mathrm{N}$ & $\mathrm{F}, \mathrm{N}$ & $\mathrm{F}, \mathrm{N}$ \\
\hline Xylopia le-testui & $\mathrm{T}$ & 2 & - & $\mathrm{F}$ & - \\
\hline Xylopia rubescens & $\mathrm{T}$ & $1 \dagger$ & $\mathrm{F}, \mathrm{E}, \mathrm{N}$ & $\mathrm{F}, \mathrm{E}, \mathrm{N}$ & $\mathrm{F}, \mathrm{N}$ \\
\hline Xylopia staudtii & $\mathrm{T}$ & $1 \dagger$ & $\mathrm{F}, \mathrm{E}$ & $\mathrm{F}$ & - \\
\hline \multicolumn{6}{|l|}{ Apocynaceae } \\
\hline Rauwolfia macrophylla & $\mathrm{T}$ & $1 \dagger$ & $\mathrm{F}$ & $\mathrm{F}, \mathrm{E}$ & $\mathrm{F}$ \\
\hline \multicolumn{6}{|l|}{ Arecaceae } \\
\hline Eremospatha macrocarpa & $\mathrm{L}$ & $3 \dagger$ & $\mathrm{F}$ & - & - \\
\hline Lacosperma secundiflorum & $\mathrm{L}$ & $1 \dagger$ & $\mathrm{F}, \mathrm{N}$ & $\mathrm{F}, \mathrm{N}$ & - \\
\hline Elaeis guineensis & $\mathrm{T}$ & 1 & $\mathrm{~F}, \mathrm{~N}$ & - & $\mathrm{F}$ \\
\hline Raphia monbuttorum & $\mathrm{T}$ & $1 \dagger$ & $\mathrm{F}, \mathrm{E}, \mathrm{N}$ & $\mathrm{F}, \mathrm{N}$ & - \\
\hline \multicolumn{6}{|l|}{ Burseraceae } \\
\hline Canarium schweinfurthii & $\mathrm{T}$ & $1 \dagger$ & $\mathrm{F}, \mathrm{E}, \mathrm{N}$ & $\mathrm{F}, \mathrm{E}, \mathrm{N}$ & $\mathrm{F}$ \\
\hline Dacryodes edulis & $\mathrm{T}$ & $3 \dagger$ & $\mathrm{F}, \mathrm{N}$ & $\mathrm{F}, \mathrm{N}$ & - \\
\hline \multicolumn{6}{|l|}{ Combretaceae } \\
\hline Terminalia superba & $\mathrm{T}$ & 4 & $\mathrm{~F}$ ? & FS & - \\
\hline \multicolumn{6}{|l|}{ Euphorbiaceae } \\
\hline Bridelia cf. atroviridis & $\mathrm{S}$ & 2 & $\mathrm{~F}$ ? & $\mathrm{F}$ ? & $\mathrm{F}$ ? \\
\hline Discoglypremna caloneura & $\mathrm{T}$ & 2 & $\mathrm{~F}$ & $\mathrm{~F}$ & $\mathrm{~F}$ \\
\hline Margaritaria discoidea & $\mathrm{T}$ & 2 & $\mathrm{~F}$ & $\mathrm{~F}$ & - \\
\hline Uapaca paludosa & $\mathrm{T}$ & 2 & $\mathrm{~F}$ & - & - \\
\hline Uapaca sp. & $\mathrm{T}$ & 1 & $\mathrm{~F}$ & $\mathrm{~F}, \mathrm{E}$ & - \\
\hline Euphorbiaceae sp.J13A & $\mathrm{T}$ & $1 \dagger$ & $\mathrm{F}$ ? & $\mathrm{F}, \mathrm{N}$ & - \\
\hline Euphorbiaceae sp. PC306 & $\mathrm{T}$ & 2 & - & $\mathrm{F}$ & - \\
\hline \multicolumn{6}{|l|}{ Hypericaceae } \\
\hline Vismia guineensis & $\mathrm{S}$ & 2 & $\mathrm{~F}$ ? & - & - \\
\hline \multicolumn{6}{|l|}{ Lauraceae } \\
\hline Beilschmiedia sp. 1 & $\mathrm{~T}$ & $1 \dagger$ & $\mathrm{F}$ & $\mathrm{F}, \mathrm{E}$ & - \\
\hline Beilschmiedia sp. 2 & $\mathrm{~T}$ & 2 & $\mathrm{~F}$ & $\mathrm{~F}$ & - \\
\hline \multicolumn{6}{|l|}{ Lecythidaceae } \\
\hline Petersianthus macrocarpus & $\mathrm{T}$ & 4 & $\mathrm{~F}$ & - & - \\
\hline \multicolumn{6}{|l|}{ Meliaceae } \\
\hline Guarea thompsonii & $\mathrm{T}$ & 1 & $\mathrm{~F}, \mathrm{E}$ & $\mathrm{F}$ & FS \\
\hline Guarea cedrata & $\mathrm{T}$ & 1 & $\mathrm{~F}, \mathrm{E}$ & $\mathrm{F}$ & $\mathrm{F}$ \\
\hline Trichillia heudelotii & $\mathrm{T}$ & $1 \S$ & $\mathrm{F}$ & $\mathrm{F}, \mathrm{E}$ & - \\
\hline Trichillia cf. gilgiana & $\mathrm{T}$ & 2 & $\mathrm{~F}$ & $\mathrm{~F}$ & - \\
\hline \multicolumn{6}{|l|}{ Moraceae } \\
\hline Ficus cf. thonningii & $\mathrm{T}$ & 2 & $\mathrm{~F}$ & $\mathrm{~F}$ & $\mathrm{~F}$ \\
\hline Ficus exasperata & $\mathrm{T}$ & 2 & - & FS & FS \\
\hline Ficus spp. & $\mathrm{L}$ & 1 & $\mathrm{~F}, \mathrm{~N}$ & $\mathrm{~F}, \mathrm{~N}$ & $\mathrm{~F}$ \\
\hline Ficus sp. Al & $\mathrm{L}$ & 2 & $\mathrm{~F}$ & $\mathrm{~F}$ & $\mathrm{~F}$ \\
\hline Ficus sp. PC225 & $\mathrm{T}$ & 2 & - & $\mathrm{F}$ & - \\
\hline Ficus sp. PC316 & $\mathrm{T}$ & 2 & $\mathrm{~F}$ & $\mathrm{~F}$ & - \\
\hline Ficus sp. PH281 & $\mathrm{L}$ & 2 & - & $\mathrm{F}$ & - \\
\hline Musanga cecropioides & $\mathrm{T}$ & 2 & $\mathrm{~F}$ & $\mathrm{~F}$ & FS \\
\hline Myristicaceae & & & & & \\
\hline Coelocaryon preussii & $\mathrm{T}$ & $1 \dagger$ & $\mathrm{F}, \mathrm{E}, \mathrm{N}$ & $\mathrm{F}, \mathrm{E}, \mathrm{N}$ & $\mathrm{N}$ \\
\hline Pycnanthus angolensis & $\mathrm{T}$ & $3 \dagger$ & $\mathrm{F}, \mathrm{E}, \mathrm{N}$ & $\mathrm{F}, \mathrm{E}, \mathrm{N}$ & $\mathrm{F}, \mathrm{N}$ \\
\hline Staudtia stipitata & $\mathrm{T}$ & $1 \dagger$ & $\mathrm{F}, \mathrm{E}, \mathrm{N}$ & $\mathrm{F}, \mathrm{E}, \mathrm{N}$ & $\mathrm{F}, \mathrm{N}$ \\
\hline
\end{tabular}


Table 2. Continued.

\begin{tabular}{|c|c|c|c|c|c|}
\hline \multirow[b]{2}{*}{ Fruit species } & \multirow{2}{*}{$\begin{array}{c}\text { Plant } \\
\text { stature }^{\mathrm{a}}\end{array}$} & \multirow{2}{*}{$\begin{array}{l}\text { Seed } \\
\text { fate }^{b}\end{array}$} & \multicolumn{3}{|c|}{ Observations $^{c}$} \\
\hline & & & C. atrata & C. cylindricus & C. fistulator \\
\hline \multicolumn{6}{|l|}{ Olacaceae } \\
\hline Heisteria zimmereri & $\mathrm{T}$ & $3 \dagger$ & $\mathrm{F}, \mathrm{N}$ & $\mathrm{F}, \mathrm{N}$ & $\mathrm{F}$ \\
\hline Strombosia pustulata & $\mathrm{T}$ & 2 & $\mathrm{~F}$ & $\mathrm{~F}$ & - \\
\hline Strombosia scheffleri & $\mathrm{T}$ & $1 \dagger$ & $\mathrm{F}, \mathrm{N}$ & $\mathrm{N}$ & - \\
\hline Strombosiopsis tetranda & $\mathrm{T}$ & 2 & $\mathrm{~F}$ & - & - \\
\hline \multicolumn{6}{|l|}{ Rhamnaceae } \\
\hline Maesopsis eminii & $\mathrm{T}$ & $1 \dagger$ & $\mathrm{F}, \mathrm{E}, \mathrm{N}$ & $\mathrm{F}, \mathrm{E}, \mathrm{N}$ & $\mathrm{F}, \mathrm{E}, \mathrm{N}$ \\
\hline \multicolumn{6}{|l|}{ Rhizophoraceae } \\
\hline Anopyxis klaineana & $\mathrm{T}$ & 4 & $\mathrm{~F}$ & $\mathrm{~F}$ ? & - \\
\hline \multicolumn{6}{|l|}{ Rubiaceae } \\
\hline Rubiaceae sp. 1 & $\mathrm{~S}$ & 2 & F? & $\mathrm{F}$ & - \\
\hline \multicolumn{6}{|l|}{ Sapindaceae } \\
\hline Blighia welwitschii & $\mathrm{T}$ & 1 & $\mathrm{~F}, \mathrm{~N}$ & $\mathrm{~F}, \mathrm{~N}$ & - \\
\hline Eriocoelum macrocarpum & $\mathrm{T}$ & 1 & $\mathrm{~F}$ & $\mathrm{~F}, \mathrm{~N}$ & - \\
\hline \multicolumn{6}{|l|}{ Sapotaceae } \\
\hline Breviea sericea & $\mathrm{T}$ & 2 & - & $\mathrm{F}$ ? & - \\
\hline \multicolumn{6}{|l|}{ Sterculiaceae } \\
\hline Eribroma oblongum & $\mathrm{T}$ & 1 & $\mathrm{~F}, \mathrm{E}$ & $\mathrm{F}, \mathrm{E}$ & $\mathrm{F}$ \\
\hline Sterculia tragacantha & $\mathrm{T}$ & 2 & - & - & $\mathrm{F}$ \\
\hline \multicolumn{6}{|l|}{ Ulmaceae } \\
\hline Celtis mildbraedii & $\mathrm{T}$ & 2 & $\mathrm{~F}$ & $\mathrm{~F}$ & - \\
\hline Celtis tessmannii & $\mathrm{T}$ & 2 & $\mathrm{~F}$ ? & - & - \\
\hline \multicolumn{6}{|l|}{ Verbenaceae } \\
\hline Vitex sp. & $\mathrm{S}$ & 1 & $\mathrm{~F}, \mathrm{~N}$ & - & - \\
\hline \multicolumn{6}{|l|}{ Unknown } \\
\hline PG113 & $\mathrm{T}$ & 2 & $\mathrm{~F}$ & $\mathrm{~F}$ & - \\
\hline PC2 10 & $\mathrm{~T}$ & 2 & - & $\mathrm{F}$ & - \\
\hline PC302 & $\mathrm{L}$ & 2 & $\mathrm{~F}$ & - & $\mathrm{F}$ \\
\hline $\mathrm{A} 17 \mathrm{~B}$ & ? & 1 & - & $\mathrm{N}$ & - \\
\hline \multicolumn{6}{|l|}{ No. species consumed } \\
\hline Trees & & & 44 & 46 & 23 \\
\hline Lianas & & & 4 & 3 & 2 \\
\hline \multirow{2}{*}{\multicolumn{6}{|c|}{ No. species dispersed ${ }^{d}$}} \\
\hline & & & & & \\
\hline Trees & & & 42 & 45 & 23 \\
\hline Lianas & & & 4 & 3 & 2 \\
\hline Total & & & 46 & 48 & 25 \\
\hline
\end{tabular}

${ }^{a}$ Plant stature: $\mathrm{T}=$ tree, $\mathrm{S}=$ small tree, $\mathrm{L}=$ liana

${ }^{\mathrm{b}}$ Seed fate:

$1=$ seeds passed without obvious physical damage (determined by inspection);

2 = seeds likely passed without obvious physical damage (based on seed/fruit morphology);

$3=$ most seeds passed without damage but some seed fragments found in nest traps;

$4=$ seeds likely predated upon (based on seed/fruit morphology);

$\dagger=$ at least some passed seeds germinated in plantings;

$\S=$ no passed seeds germinated in plantings.

${ }^{c}$ Observations:

$\mathrm{F}=$ direct observation of feeding at the BRS;

$\mathrm{FS}=$ direct observation of feeding in a secondary forest site $22 \mathrm{~km}$ to the north of the BRS;

$\mathrm{F}$ ? = circumstantial evidence of feeding;

$\mathrm{E}=$ direct observation of seed passage (defaecation or regurgitation);

$\mathrm{N}=$ seeds collected from traps under nests.

${ }^{\mathrm{d}}$ Species having seed fate codes of 1, 2 or 3 , see above. 


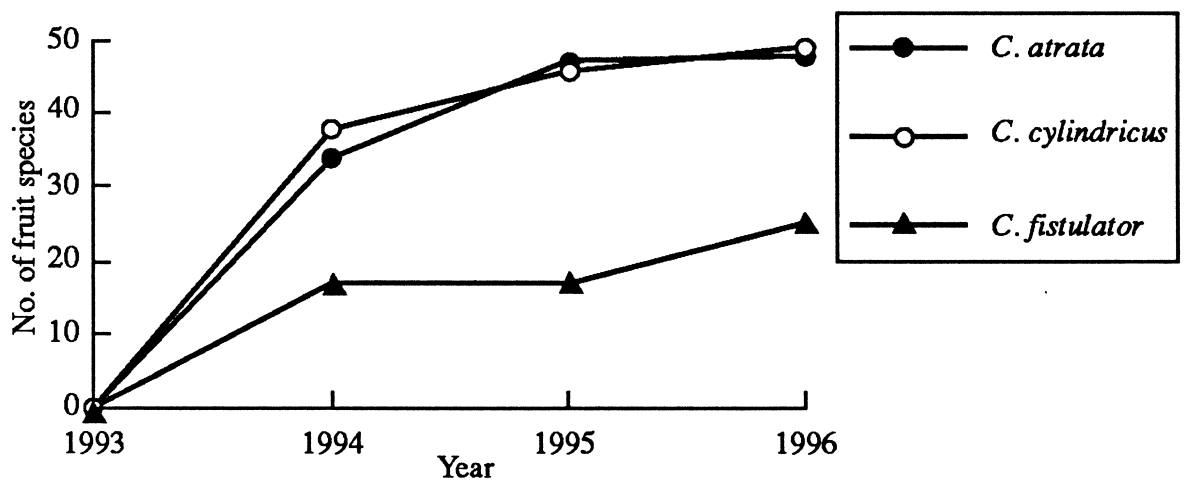

Figure 1. Cumulative numbers of fruit species recorded in Ceratogymna hornbill diets in Dja Reserve, Cameroon, 1994-1996.

Table 3. Lengths of feeding visits to fruiting trees by three Ceratogymna species at Bouamir Research Station, 1994.

\begin{tabular}{|c|c|c|c|c|c|c|c|}
\hline \multirow{4}{*}{$\begin{array}{l}\text { Tree species } \\
\text { Anacardiaceae } \\
\quad \text { Lannea welwitschii }\end{array}$} & \multirow{4}{*}{$\frac{\text { Effort }^{\mathrm{a}}}{42.8}$} & \multicolumn{6}{|c|}{ Feeding visit lengths (min) } \\
\hline & & \multicolumn{2}{|c|}{ C. atrata } & \multicolumn{2}{|c|}{ C. cylindricus } & \multicolumn{2}{|c|}{ C. fistulator } \\
\hline & & \multicolumn{2}{|c|}{$\begin{array}{l}\text { N Median } \\
(\text { Mean } \pm \text { SE })\end{array}$} & \multicolumn{2}{|c|}{$\begin{array}{l}\text { N Median } \\
(\text { Mean } \pm \text { SE })\end{array}$} & \multicolumn{2}{|c|}{$\begin{array}{l}\text { N Median } \\
(\text { Mean } \pm \text { SE })\end{array}$} \\
\hline & & 9 & $\begin{array}{c}3.0 \\
(3.7 \pm 1.0)\end{array}$ & 26 & $\begin{array}{c}11.0 \\
(18.8 \pm 4.9)\end{array}$ & 11 & $\begin{array}{c}4.0 \\
(5.2 \pm 0.8)\end{array}$ \\
\hline \multicolumn{8}{|l|}{ Annonaceae } \\
\hline Cleistopholis glauca & 131.6 & 5 & $\begin{array}{c}1.1 \\
(1.2 \pm 0.2)\end{array}$ & 35 & $\begin{array}{c}7.0 \\
(8.3 \pm 0.7)\end{array}$ & 7 & $\begin{array}{c}3.5 \\
(4.0 \pm 0.5)\end{array}$ \\
\hline Polyalthia suaveolens & 56.9 & 3 & $\begin{array}{c}2.0 \\
(4.6 \pm 3.2)\end{array}$ & 3 & $\begin{array}{c}2.8 \\
(3.5 \pm 1.1)\end{array}$ & & $\begin{array}{l}- \\
-\end{array}$ \\
\hline Xylopia hypolampra & 92.7 & 5 & $\begin{array}{c}2.0 \\
(2.9 \pm 1.1)\end{array}$ & 3 & $\begin{array}{c}1.5 \\
(1.8 \pm 0.3)\end{array}$ & 4 & $\begin{array}{c}7.1 \\
(5.7 \pm 1.8)\end{array}$ \\
\hline \multicolumn{8}{|l|}{ Apocynaceae } \\
\hline Rauwolfia macrophylla & 78.5 & 1 & $\begin{array}{c}1.8 \\
-\end{array}$ & 6 & $\begin{array}{c}3.6 \\
(9.9 \pm 5.2)\end{array}$ & & $\begin{array}{l}- \\
-\end{array}$ \\
\hline $\begin{array}{l}\text { Burseraceae } \\
\quad \text { Canarium schweinfurthii }\end{array}$ & 3.5 & 21 & $\begin{array}{c}6.0 \\
(6.4 \pm 0.5)\end{array}$ & 31 & $\begin{array}{c}8.0 \\
(8.9 \pm 0.9)\end{array}$ & & - \\
\hline \multicolumn{8}{|l|}{ Myristicaceae } \\
\hline Coelocaryon preussii & 132.6 & 92 & $\begin{array}{c}7.1 \\
(9.4 \pm 0.9)\end{array}$ & 21 & $\begin{array}{c}6.9 \\
(9.3 \pm 1.8)\end{array}$ & & $\begin{array}{l}- \\
-\end{array}$ \\
\hline Pycnanthus angolensis & 132.3 & 94 & $\begin{array}{c}5.1 \\
(9.1 \pm 1.2)\end{array}$ & 6 & $\begin{array}{c}14.3 \\
(14.8 \pm 3.9)\end{array}$ & 2 & $\begin{array}{c}17.6 \\
(17.6 \pm 0.0)\end{array}$ \\
\hline Staudtia stipitata & 158.8 & 75 & $\begin{array}{c}7.0 \\
(10.2 \pm 1.5)\end{array}$ & 90 & $\begin{array}{c}9.0 \\
(11.7 \pm 1.2)\end{array}$ & 21 & $\begin{array}{c}7.7 \\
(7.6 \pm 1.3)\end{array}$ \\
\hline $\begin{array}{l}\text { Rhamnaceae } \\
\quad \text { Maesopsis eminii }\end{array}$ & 65.0 & 26 & $\begin{array}{c}7.0 \\
(9.3 \pm 1.8)\end{array}$ & 10 & $\begin{array}{c}7.5 \\
(18.9 \pm 8.4)\end{array}$ & & - \\
\hline
\end{tabular}

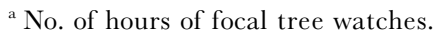


C. atrata and Staudtia stipitata

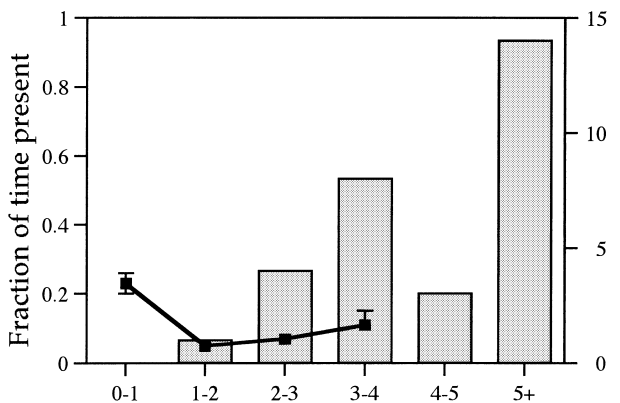

C. cylindricus and Staudtia stipitata

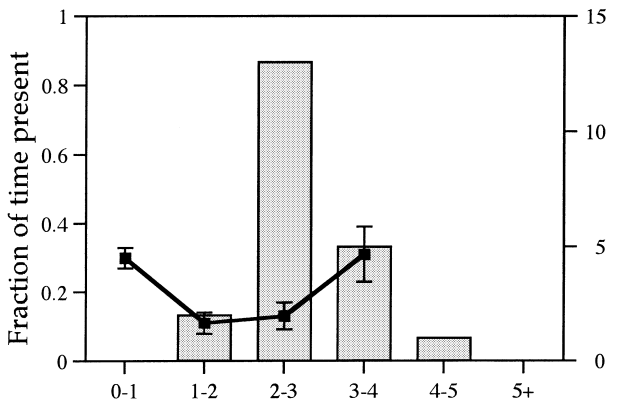

C. fistulator and Staudtia stipitata

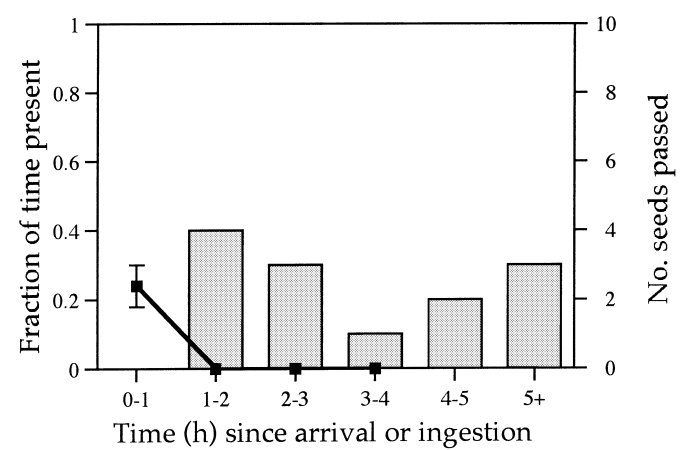

C. atrata and Maesopsis eminii

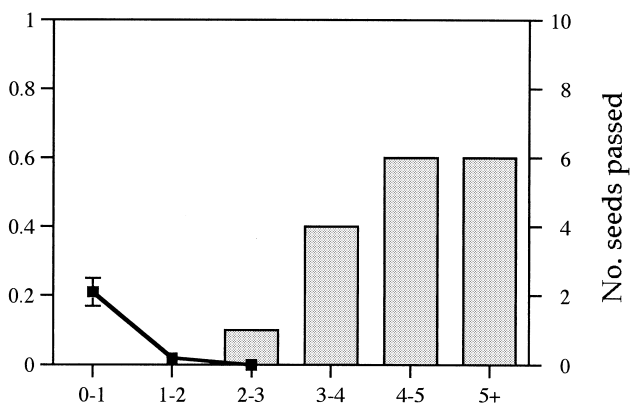

C. cylindricus and Lannea welwitschii

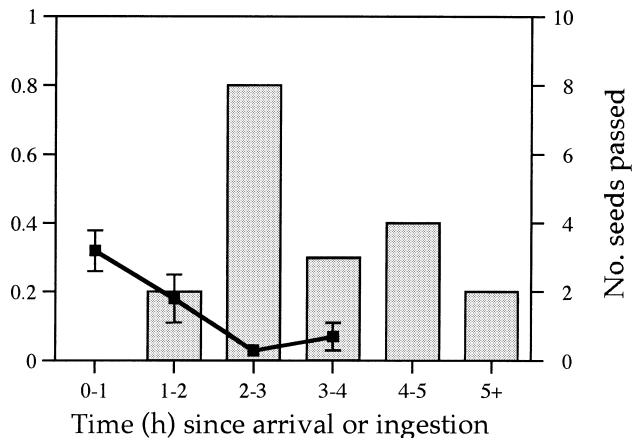

Time (h) since arrival or ingestion

Figure 2. Comparisons of the temporal pattern of hornbill visits to fruiting trees and seed passage times for five hornbill/tree species pairings. Lines represent the average $( \pm \mathrm{SE})$ fraction of time an individual hornbill was present in a tree in 1-h intervals following its arrival; thus, lines also represent the maximum fraction of seeds passed that would be expected to fall beneath the parent tree. Sample sizes (no. visits) are given in Table 3. Bars represent the number of seeds passed during 1-h intervals following ingestion in experimental trials. 
and no seed fragments (indicating destruction in the gut) were passed. Relative to visit lengths, hornbill seed passage times were long, ranging from 64765 min. Median passage times were $>2.5 \mathrm{~h}$ for each of the five tree species tested.

Comparison of the distributions of hornbill presence in fruiting trees and seed passage times for five hornbill/tree pairings (Figure 2) suggests that few seeds were passed beneath parent trees. In the first interval, when hornbill presence was highest, no seeds were passed. Of the seeds passed between 1 and $4 \mathrm{~h}$ after ingestion, it is likely that only 0 to $31 \%$ of them fell beneath the parent tree, with 69 to $100 \%$ deposited away from the parent. For the seeds passed $\geq 4 \mathrm{~h}$ after ingestion, probabilities of deposition beneath the parent are unknown, but are likely to be in the same range. Note that hornbill presence is overestimated (see Methods), and the actual percentages of seeds deposited beneath parents are likely much lower.

\section{Hornbill effects on seeds}

Thirty-four seed species passed by hornbills were collected and inspected for damage (Table 2). These seeds represented a wide range of plant families and came from a variety of fruit types, including drupes, berries, syconia and arillate fruits. The vast majority of these seeds were passed without obvious physical damage; in many cases, fruit tissue was still attached to the seed, indicating gentle treatment in the hornbill gut. For five species occasional damage was recorded from seed traps (Table 2). Of the remaining species found in Ceratogymna diets, only three - Terminalia superba (Combretaceae), Petersianthus macrocarpus (Lecythidaceae) and Anopyxis klaineana (Rhizoporaceae) - are likely to be consistently destroyed when consumed by hornbills. Fruits of these three species are either wind-dispersed samaras (T. superba and $P$. macrocarpus) or are consumed when immature (A. klaineana).

Twenty-three of 24 tree and liana species in the germination trials showed germination after passage by C. atrata and/or C. cylindricus (Table 2). The single species which did not germinate after hornbill passage, Trichilia heudelotii, had a low sample size of three seeds. Further trials would likely demonstrate that hornbills are dispersers of $T$. heudelotii and thus of all 24 species tested. More subtle effects were investigated in a subset of 17 species by comparing germination rates of passed seeds with those of controls. For most species, hornbill passage had nonsignificant (seven species) or positive (six species) effects on germination rate, while only four species experienced significant inhibition of germination rate caused by hornbill passage (Table 4).

In total, the evidence indicates that 56 of the 59 plant species consumed by hornbills are dispersed with at least some seeds surviving (Table 2), and the germination trials suggest that the majority of these species experience no drop in germination rate. 


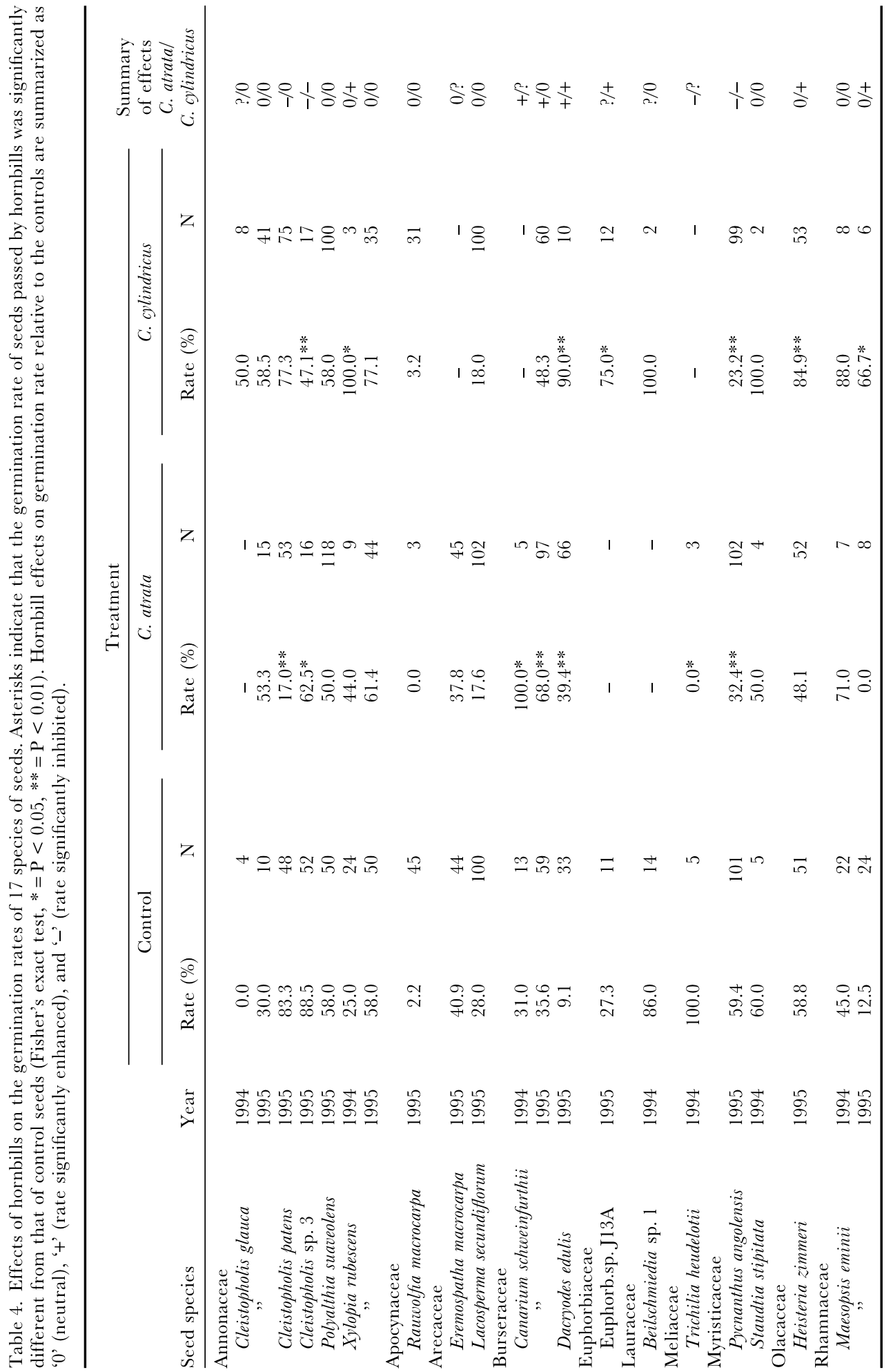




\section{DISGUSSION}

\section{Temporal patterns of hornbill visits and seed passage}

Howe \& Estabrook (1977) apparently first originated the idea that visit lengths of frugivores could influence their effectiveness as seed dispersers, and both Pratt \& Stiles (1983) and Wheelwright (1991) recognized that longer visit lengths can reduce disperser effectiveness through the higher probabilities of seed deposition beneath parent trees. However, it is the relationship between visit length, visit frequency, and seed passage time - not visit length alone which determines whether a frugivore delivers large numbers of seeds beneath the parental plant and in so doing compromises its dispersal effectiveness.

Curves of hornbill presence in fruiting trees tend to decrease at first, and then increase (Figure 2). We believe that the increase is an artifact of the sampling method rather than an accurate description of hornbill behaviour. Because tree watches were limited to $4 \mathrm{~h}$ in length, only visits that occurred soon after watches began were part of the calculation of observed presence in the third and fourth intervals. These early visits were common only in heavilyvisited fruiting trees for which hornbill presence remained high throughout the watch period. Longer sampling periods would remove this bias against visits to less-popular trees, and would likely result in presence curves that decreased continuously through time. Despite this bias, the presence curves serve as maximum estimates of hornbill presence, and show that hornbills spend little time in feeding trees during either initial or repeat visits.

Passage times reported here for five hornbill/seed species pairs appear representative of hornbill seed passage times obtained in other experimental trials and in the wild. Additional trials with five other seed species, for a total of 13 hornbill/seed pairs, resulted in passage times of 51-765 min; median passage times were $>2 \mathrm{~h}$ (K. Holbrook, unpubl. data). Seed passage times obtained experimentally may be biased due to the stresses imposed on captive birds. However, in the current study, field observations were consistent with the long seed passage times obtained in trials. A female $C$. cylindricus was observed to pass a Polyalthia (=Greenwayodendron) suaveolens seed after feeding in nonPolyalthia trees for $64 \mathrm{~min}$, making seed passage time a minimum of $64 \mathrm{~min}$. A female C. atrata regurgitated a Staudtia stipitata seed after resting in a Cleistopholis glauca tree for a minimum of $51 \mathrm{~min}$.

In sum, Ceratogymna hornbills have short visit lengths to fruiting trees relative to their seed passage times, and do not return frequently enough to trees to deposit a large fraction of the ingested seeds beneath the parent plant. To the extent that plant species addressed here conform to the escape hypothesis (Connell 1971, Janzen 1970), hornbills provide high-quality dispersal.

\section{Hornbill seed deposition characteristics}

Seed-dispersing animals either deposit seeds in clumps (e.g. elephant dung piles) or they scatter them singly (Howe 1989). These patterns have potential 
effects on seedling recruitment. For some plant species, clump deposition is detrimental to individual fitness because of the intense competition for resources in seedling clumps (Howe 1989, Loiselle 1990). Other species, however, are apparently adapted to clump dispersal; seedlings of at least one Prunus species grow better in clumps because of root-grafting (Jordano 1992). Furthermore, the faecal material present in clump defaecations such as bear scats and elephant dung piles (Alexandre 1978) may aid seedling growth. Thus the effects of scatter- and clump-deposition are likely to be species-specific.

During most of the year, Ceratogymna hornbills are scatter dispersers. Seeds are passed singly or in small groups in the high canopy, scatter as they strike vegetation on their fall through the mid-canopy and understorey, and often bounce upon hitting the ground. Even seeds passed while a bird is resting immobile on a single perch can end up $>3 \mathrm{~m}$ from each other $(\mathrm{K}$. Whitney, pers. obs.). However, during the 4-6 mo nesting season, large numbers of seeds accumulate beneath hornbill nest cavities. During this period Ceratogymna hornbills probably function primarily as clump dispersers (although when not near nest cavities, male hornbills still scatter seeds). Compared with scatter-adapted species, plant species adapted to clump dispersal should show higher levels of resistance to herbivores, pathogens, and other sources of density-dependent seed or seedling mortality (Howe 1989). It would be interesting to determine whether species dispersed by hornbills during the nesting season differ from species dispersed outside the nesting season in these expected theoretical ways.

The importance of Ceratogymna hornbills in Afrotropical forests

Based on the three criteria outlined previously, it is clear that C. atrata, $C$. cylindricus, and C. fistulator are important seed dispersers within the forests of the Dja Reserve, Cameroon. Collectively, they consume the fruits and disperse the seeds of $c .22 \%$ of the tree assemblage, deposit only a small percentage of seeds beneath parent trees (maximum of $0-31 \%$ in five interactions studied), and unlike many other frugivorous species (e.g. Gautier-Hion et al. 1985), they damage very few of the seeds they pass. The remaining four Ceratogymna species are likely to have similar seed-dispersing characteristics. Outside the present study, detailed information is only available for $C$. subcylindricus, which also has an extensive diet (Table 5) and does not appear to damage seeds (Kalina 1988).

Many of the species dispersed by Ceratogymna hornbills are community dominants, economically important to humans, or both. Strombosia pustulata, Strombosiopsis tetranda and Polyalthia suaveolens are among the 20 most abundant species in the study site as ranked by basal area (M. Fogiel, unpubl. data). Guarea spp., Celtis mildbraedii, Maesopsis eminii, Canarium schweinfurthii and at least 30 other hornbill-dispersed species are exploited for timber (see Bolza \& Keating 1972). Another group of hornbill-dispersed species, including the rattans Lacosperma secundiflorum and Eremospatha macrocarpa, the oil palm Elaeis guineensis, and the 
Table 5. Comparisons of the numbers of plant taxa dispersed by vertebrate seed dispersers in selected Afrotropical forest sites ${ }^{\mathrm{a}}$.

\begin{tabular}{|c|c|c|c|c|c|}
\hline \multirow[b]{2}{*}{ Disperser } & \multirow[b]{2}{*}{ Site } & \multirow{2}{*}{$\begin{array}{l}\text { Biomass } \\
\left(\mathrm{kg} \mathrm{km}^{-2}\right)\end{array}$} & \multicolumn{3}{|c|}{ Plant taxa dispersed } \\
\hline & & & No. genera & No. spp. & Source \\
\hline $\begin{array}{l}\text { Ceratogymna } \\
\quad \text { hornbills ( } 3 \text { spp.) }\end{array}$ & Dja Reserve, Cameroon & $19-26^{\mathrm{b}}$ & 34 & 56 & present study \\
\hline $\begin{array}{l}\text { Ceratogymna } \\
\text { subcylindricus }\end{array}$ & Kibale Reserve, Uganda & $13-28$ & $24^{c}$ & $33^{\mathrm{c}}$ & Kalina (1988) \\
\hline Pan troglodytes & Kibale Reserve, Uganda & NA & 41 & 59 & Wrangham et al. (1994) \\
\hline $\begin{array}{l}\text { Gorilla gorilla } \\
\text { Loxodonta }\end{array}$ & Lopé Reserve, Gabon & $23-78^{\mathrm{d}}$ & 37 & 65 & Tutin et al. (1991) \\
\hline africana cyclotis & Lopé Reserve, Gabon & $522-5225^{\mathrm{d}}$ & 45 & 70 & White et al. (1993) \\
\hline
\end{tabular}

${ }^{a}$ Criteria for selection were that diets were studied over three or more years at a site, and that passed seeds were examined for damage and/or germination. Data from Gautier-Hion et al. (1985) are not included because their analysis was limited to a subset of the available fruit species, resulting in underestimates of the numbers of plant taxa dispersed.

${ }^{\mathrm{b}}$ Source: Whitney \& Smith (1998).

${ }^{c}$ An additional 14 genera and 34 species are in the diet, but effects on seeds are not known.

${ }^{\mathrm{d}}$ Source: White (1994).

raphia palm Raphia monbuttorum, are non-timber forest products used extensively within Central Africa.

Hornbill frugivory and seed dispersal takes place within the context of a large and varied assemblage of Afrotropical forest frugivores. Roles in seed dispersal have been suggested for elephants (Alexandre 1978, Chapman et al. 1992, Feer 1995a, Gautier-Hion et al. 1985, White et al. 1993, Yumoto et al. 1995), gorillas (Tutin et al. 1991), chimpanzees (Wrangham et al. 1994), cercopithecine monkeys (Gautier-Hion 1984, Gautier-Hion et al. 1985), bats (Marshall 1983, 1985), ruminants (Feer 1995b, Gautier-Hion et al. 1985), rodents (Gautier-Hion et al. 1985), bulbuls (Graham et al. 1995) and tauracos (Gautier-Hion et al. 1985). Where do Ceratogymna hornbills fit within this speciose assemblage? This is a difficult question for several reasons. First, little is known about seed dispersal for many taxa of plants and animals, and multipleyear studies of dispersal are rare. Second, even when disperser-plant interactions have been studied adequately, they are rarely expressed as a percentage of the flora making inter-site comparisons difficult. Third, seed dispersal by two related primate species has been shown to vary markedly between sites (Gautier-Hion et al. 1993), suggesting caution in generalizing roles in seed dispersal from single-site studies. Nevertheless, it is clear that the taxonomic diversity of hornbill-dispersed plants can be comparable to that dispersed by the most important mammalian seed dispersers (Table 5). Overlap with these other dispersers is apparently low; for two floristically similar sites (the Dja and the Lopé Reserve, Gabon), elephants and hornbills share only five genera, while gorillas and hornbills share only seven genera (Tutin et al. 1991, White et al. 1993, the present study). This suggests that, even though associations between frugivores and morphological syndromes of fruit may be less rigid than 
previously thought (Gautier-Hion et al. 1985), there may be little ecological redundancy between disperser groups.

\section{Conservation implications}

In the Afrotropics and elsewhere, large forest hornbills deserve increased conservation status. Based on the number of species for which they provide safe seed dispersal away from the parent plant, hornbills in the genus Ceratogymna may well be integral to healthy dynamics in equatorial African forests. A similar picture is emerging in Asian forests; Leighton (1981) and Kinnaird (in press) have demonstrated that large Asian forest hornbills have broad diets and generally disperse seeds unharmed. Ceratogymna hornbills are common in both mature and secondary forests in the Dja region (Whitney \& Smith, 1998), suggesting that they may be important in seed dispersal in regenerating habitats. Given the propensity of humans to extirpate large mammals from remnant forest patches, Ceratogymna hornbills may become increasingly important in forest regeneration as populations of larger mammalian seed-dispersing species (such as forest elephants and primates) diminish. An analogous situation may already exist in some Asian sites; in Sulawesi, hunting has differentially reduced populations of large primates and ungulates relative to hornbills. Large forest hornbills in Asia have wide-ranging behaviours and extensive habitat needs (Kinnaird in press, Kinnaird et al. 1996, Leighton \& Leighton 1983, O’Brien et al. 1996, Poonswad \& Tsuji 1994), and preliminary data suggest the same is true for African Ceratogymna hornbills (Whitney \& Smith, 1998). The ranging behaviours and habitat needs of hornbills and other large seed dispersers may make the conservation of Old World tropical forests particularly difficult.

\section{AGKNOWLEDGEMENTS}

We are grateful to the government of the Republic of Cameroon, in particular the Ministry of Environment and Forests (MINEF) and the Ministry of Higher Education and Scientific Research (MINREST), for permission to conduct this research. In particular we wish to thank J. M. Mengang, J.-P. Boyogueno, and V. S. Balinga. Financial and logistical support were generously provided by NYZS/The Wildlife Conservation Society, the National Science Foundation Graduate Fellowship Program, the GAANN Program of San Francisco State University, and ECOFAC Cameroun. The NSF-GRT Program of University of California, Davis, and SFSU is acknowledged for support during the analysis phase. For dedicated and skillful assistance in the field we thank S. Benge, M. Biederman, A. L. Bowersox, C. J. Clark, B. L. Demarest, F. E. Eanet, A. R. French, C. Gjerdrum, E. R. Hekkala, N. A. Helme, C. Hess, D. A. Kilimnik, M. Kimura, D. LeFer, D. Marnel, J. R. Poulsen, T. W. Richardson, M. R. Russell, R. E. Rynning, J. G. Schuetz, A. P. Smyth, D. Sonwa, E. Springborn, J. Witkin, T. A. Worth and G. M. Yanega. Residents of Bifolone and Somalomo, particularly 
A. Siec, D. Amazieh and B. Bokama, generously shared their knowledge of the forest with us. Readings by A. C. Kemp and one anonymous reviewer greatly improved the manuscript. We wish to acknowledge the unique contributions of J.-M. Froment, J.-P. Vautherin, R. C. Fotso, P. Muchaal, S. Weise, B. Brennand, S. Scheffler and T. \& H. Hockey, without whom this work would not have been possible.

\section{LITERATURE CITED}

ALEXANDRE, D. Y. 1978. Le role disseminateur des elephants en forêt de Taï, Côte-d'Ivoire. Revue d'Ecologie (Terre et Vie) 32:47-71.

BENDER, E. A., CASE, T. J. \& GILPIN, M. E. 1984. Perturbation experiments in community ecology: theory and practice. Ecology 65:1-13.

BOLZA, E. \& KEATING, W. G. 1972. African timbers - the properties, uses, and characteristics of 700 species. Division of Building Research, CSIRO, Australia. 751 pp.

BROSSET, A. \& ERARD, C. 1986. Les oiseaux des regions forestieres du nord-est du Gabon. Vol. 1: écologie et comportement des especes. Revue d'Écologie (Terre et Vie), Supplement 3. Societe National de Protection de la Nature, Paris. 297 pp.

BUSTAMANTE, R. O. \& CANALS, M. 1995. Dispersal quality in plants: how to measure efficiency and effectiveness of a seed disperser. Oikos 73:133-136.

CHAPMAN, C. A. \& CHAPMAN, L. J. 1995. Survival without dispersers: seedling recruitment under parents. Conservation Biology 9:675-678.

CHAPMAN, C. A. \& CHAPMAN, L. J. 1996. Frugivory and the fate of dispersed and non-dispersed seeds of six African tree species. Journal of Tropical Ecology 12:491-504.

CHAPMAN, L. J., CHAPMAN, C. A. \& WRANGHAM, R. W. 1992. Balanites wilsoniana: elephant dependent dispersal? Journal of Tropical Ecology 8:275-283.

CHRISTY, P. 1994. Inventaire ornithologique de la Reserve de la Faune du Dja. Rapport Intermediaire, Projet ECOFAC, Composante Cameroun.

CONNELL, J. H. 1971. On the role of natural enemies in preventing competitive exclusion in some marine mammals and in rain forest trees. Pp. 298-312 in Boer, P. J. D. \& Gradwell, G. (eds). Dynamics of populations. PUDOC, Wageningen.

DOWSETT-LEMAIRE, F. 1988. Fruit choice and seed dissemination by birds and mammals in the evergreen forests of upland Malawi. Revue d'Ecologie (Terre et Vie) 43:251-85.

FEER, F. 1995a. Morphology of fruits dispersed by African forest elephants. African Journal of Ecology 33:279-284

FEER, F. 1995b. Seed dispersal in African forest ruminants. Journal of Tropical Ecology 11:683-689.

GAUTIER-HION, A. 1984. La dissémination des graines par les cercopithèques forestiers Africains. Revue d'Ecologie (Terre et Vie) 39:159-65.

GAUTIER-HION, A., DUPLANTIER, J.-M., QURIS, R., FEER, F., SOURD, G., DECOUX, J.-P., DUBOST, G., EMMONS, L., ERARD, C., HECKETSWEILER, P., MOUNGAZI, A., ROUSSILHON, C. \& THIOLLAY, J.-M. 1985. Fruit characters as a basis of fruit choice and seed dispersal in a tropical forest vertebrate community. Oecologia 65:324-337.

GAUTIER-HION, A., GAUTIER, J. P. \& MAISELS, F. 1993. Seed dispersal versus seed predation: an inter-site comparison of two related African monkeys. Vegetatio 107/108:237-244.

GRAHAM, C. H., MOERMOND, T. C., KRISTENSEN, K. A. \& MVUKIYUMWAMI, J. 1995. Seed dispersal effectiveness by two bulbuls on Maesa lanceolata, an African montane forest tree. Biotropica 27:479-486.

HERRERA, G. M. 1984. A study of avian frugivores, bird-dispersed plants, and their interaction in Mediterranean scrublands. Ecological Monographs 54:1-23

HERRERA, C. M. 1995. Plant-vertebrate seed dispersal systems in the Mediterranean: ecological, evolutionary, and historical determinants. Annual Review of Ecology and Systematics 26:705-727.

HOWE, H. F. 1983. Annual variation in a neotropical seed-dispersal system. Pp. 211-227 in Sutton, S. L., Whitmore, T. C. \& Chadwick, A. C. (eds). Tropical rain forest: ecology and management. Blackwell Scientific Publications, Oxford.

HOWE, H. F. 1984. Implications of seed dispersal by animals for tropical reserve management. Biological Conservation 30:261-281.

HOWE, H. F. 1986. Consequences of seed dispersal by birds: a case study from Central America. Journal of the Bombay Natural History Society (Supplement) 83:19-42.

HOWE, H. F. 1989. Scatter- and clump-dispersal and seedling demography: hypothesis and implications. Oecologia 79:417-426. 
HOWE, H. F. 1990. Seed dispersal by birds and mammals: implications for seedling demography. Pp. 191-218 in Bawa, K. S. \& Hadley, M. (eds). Reproductive ecology of tropical forest plants. UNESCO, Paris.

HOWE, H. F. \& ESTABROOK, G. F. 1977. On intraspecific competition for avian dispersers in tropical trees. American Naturalist 111:817-832.

HOWE, H. F., SCHUPP, E. W. \& WESTLEY, L. C. 1985. Early consequences of seed dispersal for a neotropical tree (Virola surinamensis). Ecology 66:781-91.

HOWE, H. F. \& VANDE KERCKHOVE, G. A. 1981. Removal of wild nutmeg (Virola surinamensis) crops by birds. Ecology 62:1093-1106.

IUCN (International Union for the Conservation of Nature). 1987. The IUCN directory of Afrotropical protected areas. International Union for the Conservation of Nature, Gland, Switzerland. 1034 pp.

JANZEN, D. H. 1970. Herbivores and the number of tree species in tropical forests. American Naturalist 104:501-528.

JORDANO, P. 1992. Fruits and frugivory. Pp. 105-156 in Fenner, M. (ed.). Seeds: the ecology of regeneration in plant communities. CAB International, Wallingford, UK.

KALINA, J. 1988. Ecology and behaviour of the black-and-white casqued hornbill Bycanistes subcylindricus subquadratus in Kibale forest, Uganda. Ph. D. thesis, Michigan State University.

KEMP, A. C. 1995. The hornbills. Oxford University Press, Oxford. 302 pp.

KINNAIRD, M. F. in press. Evidence for effective seed dispersal by the Sulawesi red-knobbed hornbill, Aceros cassidix. Biotropica.

KINNAIRD, M. F., O'BRIEN, T. G. \& SURYADI, S. 1996. Population fluctuation in Sulawesi red-knobbed hornbills: tracking figs in space and time. Auk 113:431-440.

LACLAVÈRE, G., (ed.) 1980. Atlas of the United Republic of Cameroon. Editions Jeune Afrique, Paris. 72 pp.

LEIGHTON, M. 1981. Fruit resources and patterns of feeding, spacing, and grouping among sympatric Bornean hornbills (Bucerotidae). Ph. D. thesis, University of California, Davis.

LEIGHTON, M. \& LEIGHTON, D. R. 1983. Vertebrate responses to fruiting seasonality within a Bornean rain forest. Pp. 181-196 in Sutton, S. L., Whitmore, T. C. \& Chadwick, A. C. (eds). Tropical rain forest: ecology and management. Blackwell Scientific Publications, Oxford.

LETOUZEY, R. 1968. Études phytogéographiques du Cameroun. Editions Paul Lechevalier, Paris. 511 pp.

LOISELLE, B. A. 1990. Seeds in droppings of tropical fruit-eating birds: importance of considering seed composition. Oecologia 82:494-500.

MARSHALL, A. G. 1983. Bats, flowers, and fruit: evolutionary relationships in the Old World. Biological Journal of the Linnean Society 20:115-135.

MARSHALL, A. G. 1985. Old World phytophagous bats (Megachiroptera) and their food plants: a survey. Zoological Journal of the Linnean Society 83:351-69.

MILlS, L. S., SOULÉ, M. E. \& DOAK, D. F. 1993. The keystone-species concept in ecology and conservation. BioScience 43:219-224.

O'BRIEN, T. G., KINNAIRD, M. F., JEPSON, P. \& SETIAWAN, I. 1996. Effect of forest size and structure on the distribution of Sumba wreathed hornbill, Aceros everetti. In Poonswad, P. (ed.) Proceedings of the Second Annual Asian Hornbill Workshop, Bangkok, Thailand.

PIMENTEL, R. A. \& SMITH, J. D. 1990. Bio tat I. Sigma Soft, Placentia, CA.

POONSWAD, P. \& TSUJI, A. 1994. Ranges of males of the great hornbill Buceros bicornis, brown hornbill Ptilolaemus tickelli and wreathed hornbill Rhyticeros undulatus in Khao Yai National Park, Thailand. Ibis 136:79-86.

PRATT, T. K. \& STILES, E. W. 1983. How long fruit-eating birds stay in the plants where they feed: implications for seed dispersal. American Naturalist 122:797-805.

SCHUPP, E. W. 1993. Quantity, quality and the effectiveness of seed dispersal by animals. Vegetatio 107/ 108:15-29.

STILES, E. W. 1992. Animals as seed dispersers. Pp. 87-104 in Fenner, M. (ed.). Seeds: the ecology of regeneration in plant communities. CAB International, Wallingford.

STILES, F. G. 1985. On the role of birds in the dynamics of neotropical forests. Pp. 49-59 in Diamond, A. W. \& Lovejoy, T. E. (eds). Conservation of tropical forest birds. ICBP technical publication no. 4. International Council for Bird Preservation, Cambridge.

TUTIN, G. E. G., WILliamSON, E. A., ROGERS, M. E. \& FERNANDEZ, M. 1991. A case study of a plant-animal relationship: Cola lizae and lowland gorillas in the Lopé Reserve, Gabon. Journal of Tropical Ecology 7:181-199.

WHEELWRIGHT, N. T. 1991. How long do fruit-eating birds stay in the plants where they feed? Biotropica 23:29-40.

WHITE, L. J. T. 1994. Biomass of rain forest mammals in the Lopé Reserve, Gabon. Journal of Animal Ecology 63:499-512.

WHITE, L. J. T., TUTIN, C. E. G. \& FERNANDEZ, M. 1993. Group composition and diet of forest elephants, Loxodonta africana cyclotis Matschie 1900, in the Lopé Reserve, Gabon. African Journal of Ecology 31:181-99. 
WHITNEY, K. D. \& SMITH, T. B. in press. Habitat use and resource tracking by African Ceratogymna hornbills: implications for seed dispersal and forest conservation. Animal Conservation 1:107-117.

WILLSON, M. F. 1992. The ecology of seed dispersal. Pp. 61-85 in Fenner, M. (ed.). Seeds: the ecology of regeneration in plant communities. $\mathrm{CAB}$ International, Wallingford, UK.

WRANGHAM, R. W., CHAPMAN, C. A. \& CHAPMAN, L. J. 1994. Seed dispersal by forest chimpanzees in Uganda. Journal of Tropical Ecology 10:355-368.

YUMOTO, T., MARUHASHI, T., YAMAGIWA, J. \& MWANZA, N. 1995. Seed-dispersal by elephants in a tropical rain forest in Kahuzi-Biega National Park, Zaïre. Biotropica 27:526-530. 